\title{
Metabolic risk factors of ovarian cancer: a review
}

\author{
Neda Khanlarkhani ${ }^{1}$, Elham Azizi ${ }^{2}$, Fardin Amidi ${ }^{3}$, Mahshad Khodarahmian ${ }^{4}$, Ensieh Salehi ${ }^{5}$, Azar Pazhohan ${ }^{6}$, \\ Bagher Farhood7, Keywan Mortezae ${ }^{8}$, Nasser Hashemi Goradel ${ }^{9}$, Maryam Shabani Nashtaei ${ }^{10}$
}

\author{
${ }^{1}$ Department of Physiology and Pharmacology, Karolinska Institute, Sweden \\ ${ }^{2}$ Department of Biology and Anatomical Sciences, School of Medicine, Shahid Beheshti University of Medical \\ Sciences, Tehran, Iran \\ ${ }^{3}$ Department of Anatomy, School of Medicine, Tehran University of Medical Sciences, Tehran, Iran \\ ${ }^{4}$ Infertility department, Arash Women's Hospital, Tehran University of Medical Sciences, Tehran, Iran \\ ${ }^{5}$ Department of Gynecology, School of Medicine, Fertility and Infertility Research Center, Dr. Ali Shariati Hospi- \\ tal, Shahid Mohammadi Hospital, Hormozgan University of Medical Sciences, Hormozgan, Iran \\ ${ }^{6}$ Infertility Center, Academic Center for Education, Culture and Research, East Azarbaijan, Tabriz, Iran. / De- \\ partment of Midwifery, Urmia Branch, Islamic Azad University, Urmia, Iran \\ ${ }^{7}$ Departments of Medical Physics and Radiology, Faculty of Paramedical Sciences, Kashan University of Medical \\ Sciences, Kashan, Iran \\ ${ }^{8}$ Department of Anatomy, School of Medicine, Kurdistan University of Medical Sciences, Sanandaj, Iran \\ ${ }^{9}$ Department of Medical Biotechnology, School of Advanced Technologies in Medicine, Tehran University of Med- \\ ical Sciences, Tehran, Iran \\ ${ }^{10}$ Department of Anatomy, School of Medicine, Tehran University of Medical Sciences, Tehran, Iran. / Infertility \\ Department, Shariati Hospital, Tehran University of Medical Sciences, Tehran, Iran
}

\begin{abstract}
Ovarian cancer continues to be the leading cause of death from gynecological cancers. Despite inconsistent results, patients with metabolic abnormalities, including obesity and diabetes mellitus (DM), have poorer outcomes, showing a correlation with ovarian cancer incidence and ovarian cancer survival. Since ovarian cancer is the most common cancer in women, and considering the increasing prevalence of obesity and DM, this paper reviews the literature regarding the relationship between the aforementioned metabolic derangements and ovarian cancer, with a focus on ovarian cancer incidence, mortality, and likely mechanisms behind them. Several systematic reviews and meta-analyses have shown that obesity is associated with a higher incidence and poorer survival in ovarian cancer. Although more studies are required to investigate the etiological relation of DM and ovarian cancer, sufficient biological evidence indicates poorer outcomes and shorter survival in DM women with ovarian cancer. A variety of pathologic factors may contribute to ovarian cancer risk, development, and survival, including altered adipokine expression, increased levels of circulating growth factors, altered levels of sex hormones, insulin resistance, hyperinsulinemia, and chronic inflammation. Thus, obesity and DM, as changeable risk factors, can be targeted for intervention to prevent ovarian cancer and improve its outcomes.
\end{abstract}

Keywords: ovarian cancer, diabetes mellitus, obesity, insulin resistance, inflammation

\section{INTRODUCTION}

Ovarian cancer is the seventh most common neoplasia and the fifth leading cause of cancer-related death in women worldwide (Ferlay et al., 2015). Incidence and mortality rates of the disease have been reported to be higher in more developed countries (Torre et al., 2015). Lower survival in ovarian cancer can chiefly be attributed to the fact that the vast majority of women with ovarian cancer is diagnosed in the advanced stage of the disease with intraperitoneal metastasis (Siegel et al., 2018; Protani et al., 2012).

Various ovarian cancer risk factors have been identified, including age, reproductive history, modifiable lifestyle factors, family history, and genetic mutations (Collaborative Group on Epidemiological Studies of Ovarian Cancer, 2008; Barry et al., 2014; Collaborative Group on Epidemiological Studies of Ovarian Cancer, 2012; Pennington \& Swisher, 2012). Ovarian cancer cells use adipocytes as an energy source for growth and migration (Nieman et al., 2011). However, the prevalence of metabolic derangements, since modifiable lifestyle factors, such as obesity, type II diabetes mellitus (DM), and metabolic syndrome has grown dramatically in most parts of the world. Recent reports show that there is an association between each of these conditions and ovarian cancer (Siegel et al., 2018; Protani et al., 2012; Olsen et al., 2007; Shah et al., 2014; Lauby-Secretan et al., 2016).

Overweight [BMI (body mass index) $\geq 25$ ] and obesity $(B M I \geq 30)$ have become epidemic worldwide, and their prevalence in women has more than doubled within the past four decades (NCD-RisC, 2016). Moreover, recent studies have also described an association between increased BMI and enhanced risk of ovarian cancer (Collaborative Group on Epidemiological Studies of Ovarian Cancer, 2008; Olsen et al., 2013), and reported the adverse effects of obesity on survival of women with ovarian cancer (Protani et al., 2012; Bae et al., 2014; Yang et al., 2011). The obesity-related comorbidities, such as type 2 DM, have also become more prevalent globally (Danaei et al., 2011; $\mathrm{Kim}, 2011$ ). About $60 \%$ of adults with DM also have obesity, and $80 \%$ of them have a BMI $>25$ as well (Iglay et al., 2016). Previous studies have indicated the relationship between DM and poorer cancer outcomes and shorter survival in women with ovarian cancer; however, the detailed link between DM and ovarian cancer is still unknown (Shah et al., 2014; Bakhru et al., 2011). Additionally, the results 
of a meta-analysis in 2012 showed a moderately increased risk of ovarian cancer in women with DM (Lee et al., 2013).

Since ovarian cancer is an associated public health issue, gaining a profound understanding of its major risk factors, especially preventable ones, such as metabolic risk factors, can be critical and should consequently be considered to develop preventive measures. Hence, the purpose of this review is to present an overview of the recent evidence regarding the association between metabolic dysregulations (obesity and type II DM) and ovarian cancer incidence and survival, and also the potential underlying biological mechanisms.

\section{OBESITY AND OVARIAN CANCER INCIDENCE}

Cancer cells often manifest altered metabolic pathways and provide energy from fat metabolites such as fatty acids, glucose, and cholesterol that contribute to the growth of ovarian cancer. Also, fatty acids are crucial for the cell membrane and protein modification in cancer cells (Munir et al., 2019). So, the excess source of energy in the human body may enhance the risk of carcinogenesis (Bianchini et al., 2002). It has been demonstrated that excess body weight is a preventable risk factor for several types of cancers (Calle et al., 2003; Renehan et al., 2008; Boeing, 2013). Evidence suggests the associations of ovarian cancer risk with sphingolipids, total cholesterol, triacylglycerol, and negative association of this cancer with high-density lipoproteins (Zeleznik et al., 2020). The association of obesity with ovarian cancer risk has been extensively evaluated by various studies. However, there is a critical need to address the inconsistent findings in the literatures (Craig et al., 2016).

The American Institute for Cancer Research and the World Cancer Research Fund recently declared that greater body fatness (marked by BMI) is a probable risk factor for ovarian cancer. According to the Ovarian Cancer 2014 Report (Continuous Update Project), there was an increased ovarian cancer risk of $6 \%$ per 5 BMI units, despite the substantial heterogeneity between investigated studies such as tumor type, use of hormone therapy, and menopause (Mayne et al., 2016). Besides, a growing body of studies has shown that increased BMI can enhance the risk of ovarian cancer (Poorolajal et al., 2014; Calle et al., 2003; Wolk et al., 2001; Dal Maso et al., 2002; Engeland et al., 2003; Rodriguez et al., 2002; Fairfield et al., 2002; Nagle et al., 2015). This association is even highlighted by a recently published meta-analysis, indicating that the highly significant increased risk of ovarian cancer accompanies the increased body weight in Caucasian and Asian premenopausal women. Of note, in particular, severe obesity revealed a stronger risk effect (Liu et al., 2015). In terms of offering a more accurate estimate of true visceral adiposity and, consequently, the risk of obesity-related cancers, the waist-to-hip ratio can be assessed instead of BMI. However, many more studies are needed for a more comprehensive analysis of this association (Renehan et al., 2008).

Ovarian cancer has several histologic subtypes' reflecting different developmental pathways (Kurman \& Shih, 2008). Herein, it is worth mentioning an association that is slightly more positive for invasive endometrioid, borderline serous, and the invasive mucinous tumors with the exception of invasive serous cancer, which is the most fatal subtype (Olsen et al., 2013). Likewise, higher risks were reported for borderline serous tumors and invasive mucinous tumors in a meta-analysis of 47 studies (Collaborative Group on Epidemiological Studies of Ovarian Cancer, 2012). In contrast, in a population-based case-control study, the overall association was just found for clear cell subtype (Olsen et al., 2008). A Mendelian randomization study, evaluated a number of 39 studies of the International Ovarian Cancer Association Consortium, used genetic markers as proxies for risk factors and provided clear evidence that genetically predicted increasing BMI (per 5 $\mathrm{kg} / \mathrm{m}^{2}$ ) was associated with enhanced risk of low grade serous ovarian cancers (Dixon et al., 2016). Moreover, the researchers of the latter study also found that consistent with previous observational studies, the association was strongest for low grade/borderline serous cancers (Dixon et al., 2016). Recently, Fortner et al. (2019) studied 1.3 million women with ovarian cancer and reported that the high BMI was only associated with a higher risk of highly aggressive ovarian cancer, regardless of the tumor subtype.

Remarkably, the time at which obesity progresses throughout a woman's life may be an essential risk factor for ovarian cancer. A positive association between elevated BMI in adolescence/early adulthood and increased risk for epithelial ovarian cancer has been determined by numerous studies (Dixon et al., 2016; Anderson et al., 2004; Engeland et al., 2003; Lubin et al., 2003). In addition, in a Norwegian cohort of approximately 1.1 million women, followed for an average of 25 years, an increased BMI in adolescence was more likely associated with epithelial ovarian cancer in adulthood. Nonetheless, no correlation between adult BMI and ovarian cancer risk was revealed (Engeland et al., 2003). Furthermore, a higher ovarian cancer risk has been demonstrated in premenopausal women who were overweight or obese compared to postmenopausal women (Liu et al., 2015; Reeves et al., 2007; Olsen et al., 2007).

The association between body size (height and BMI) and the risk of ovarian cancer was also investigated by the Collaborative Group on Epidemiological Studies of Ovarian Cancer in an individual participant meta-analysis including 47 Epidemiological Studies (Collaborative Group on Epidemiological Studies of Ovarian Cancer, 2012). Hormone therapy for menopause had a considerable effect on this association, indicating increased relative risk of ovarian cancer among obese women who never used hormone therapy, confirming the modifying effect of hormone therapy (Leitzmann et al., 2009). Besides, a dose-response meta-analysis of prospective observational studies assessed the association between adult weight gain and adiposity-related cancers, showing a $13 \%$ increase in the risk of developing ovarian cancer per every $5 \mathrm{~kg}$ increase in weight gain in postmenopausal women with no- or low-hormone replacement therapy (Keum et al., 2015).

\section{OBESITY AND OVARIAN CANCER SURVIVAL}

Ovarian cancer is a highly fatal disease due to its poor prognosis, with a 5 -year survival rate of less than $50 \%$, and a ten-year survival rate of about $35 \%$ (Sankaranarayanan \& Ferlay, 2006; Baldwin et al., 2012). Its poor survival is mainly attributed to its insidious onset, resulting in high proportions of metastatic spread beyond the pelvis upon diagnosis (Protani et al., 2012; Howlader et al., 2011). Several known prognostic indicators of survival time have been indicated, like age at diagnosis, tumor grade, and success of debulking surgery (Protani et al., 2012; Yang et al., 2011).

Among potentially modifiable prognostic factors, obesity, and excess fat in adipose tissue have been found to result in the poor prognosis for gynecological cancers (Calle et al., 2003; Rodriguez et al., 2002; Pavelka et al., 2006; Zhang et al., 2005). It has been reported that ovarian cancer mortality can be affected by obesity influencing tumor biology (Bae et al., 2014).

Moreover, it's been progressively documented that adipose tissue is a crucial component of the ovarian cancer 
metastatic microenvironment, functioning as a lipid reservoir to maintain the high-energy demands of cancer cells (Nieman et al., 2011; Colvin, 2014). Tumor strongly affects ovarian cancer metastatic success through variations in lipid regulatory factors, increased vascularity, and decreased infiltration of M1 macrophages, leading to the negative correlation between obesity and ovarian cancer survival (Liu et al., 2015).

Triacylglycerols, which compose the main part of lipid species in adipose tissue of the normal human body, produce fatty acids during their synthesis or breakdown (Al-Sulaiti et al., 2018). Obesity promotes the hypertrophy of adipocytes within adipose tissue and accumulates the excess triacylglycerol (Al-Sulaiti et al., 2018). Triacylglycerols are also associated with the inflammatory cytokine IL-6 in adipose tissue (Al-Sulaiti et al., 2018). Notably, triacylglycerol is associated with higher risk of serous ovarian tumors (Zeleznik et al., 2020). Dysregulation of lipid metabolism and the biosynthesis of triacylglycerol from fatty acids in ovarian cancer leads to the enhanced migration and metastasis of the cancer cells (Zeleznik et al., 2020). Moreover, evidence suggests that the level of circulating triacylglycerol may be a useful biomarker for ovarian cancer (Zeleznik et al., 2020).

In the study by Poole et al. (2016), it has been proposed that pre-diagnostic BMI, as one modifiable lifestyle factors, might affect the survival of ovarian cancer patients, and low pre-diagnostic BMI might be associated with a better prognosis. Moreover, a comprehensive meta-analysis ran by Bae et al. (2014) reported that despite the ambiguity of the connection between obesity at diagnosis and ovarian cancer patients' survival, obesity five years before the diagnosis of ovarian cancer and obesity at a young age were related to poor prognosis. They suggested that BMI at diagnosis cannot be used as a prognostic factor for ovarian cancer patients' survival (Bae et al., 2014). Likewise, a previous meta-analysis of studies reported higher mortality among those suffering from obesity during early adulthood or before diagnosis, although there was no correlation with obesity found around the time of diagnosis (Yang et al., 2011). Furthermore, an international collaborative analysis using the results from the Ovarian Cancer Association Consortium was undertaken to evaluate the association between pre-diagnosis BMI, progression-free survival, ovarian cancer-specific survival, and overall survival among women with invasive ovarian cancer. Intriguingly, the adverse relation between obesity and ovarian cancer survival seemed consistent regardless of the time of BMI measurement. Considering tumor histologic subtypes, positive but statistically non-significant associations were strongest for women with low-grade serous and endometrioid subtypes. In contrast, only the high-grade serous cancers revealed a borderline significant positive association with survival (Nagle et al., 2015). Furthermore, it has been reported that pre-diagnosis obesity could increase the risk of mortality in ovarian cancer patients (Zamorano et al., 2019). In general, compared with women within the normal-weight range, obese women showed poorer progression-free and overall survival. Therefore, it seems that retaining a normal BMI can be a powerful preventive tool.

Additionally, several studies have investigated the effects of BMI on surgical morbidity and clinical outcomes in ovarian cancer patients. A recent meta-analysis of five studies showed that obesity is linked with more wound complications and a longer hospital stay for these patients. However, there were no significant differences between obese and non-obese patients regarding other operative outcomes, including cytoreduction status, estimated blood loss, operation time, transfusion rates, and 30-day mortality (Smits et al., 2016). Besides, it was reported that weight loss therapy in the case of a 41 -years old woman with end-stage ovarian cancer could improve cancer and transform it into small ovarian cysts (Oshakbayev et al., 2014). Therefore, elimination of obesity, as a modifiable factor, may prolong the life of ovarian cancer patients. However, it is noteworthy that a recent clinical study demonstrated that the pre-diagnostic physical activity of patients with ovarian cancer is not associated with mortality (Zamorano et al., 2019).

Chemoresistance is also a major problem in patients with ovarian cancer (Han et al., 2018). On the other hand, treatment strategies may also be different in obese patients with epithelial ovarian cancer. Obese patients are at a particular risk of receiving inappropriate low doses of chemotherapy, owing to toxicity concerns and dose capping practices, compromising their progression-free and overall survival. Chemotherapy dosing should be adjusted based on body surface area, using actual weight according to the existing clinical guidelines (Horowitz \& Wright, 2015; Griggs et al., 2012).

However, although the studies mentioned above indicate that BMI can be associated with ovarian cancer survival, some studies have not found any evidence of this association (Tyler et al., 2012; Barrett et al., 2008; Fotopoulou et al., 2011). Thus, to elucidate the various effects of obesity on survival rates, we need more well-designed studies.

\section{MECHANISMS ASSOCIATING OBESITY TO OVARIAN CANCER}

The related mechanisms contributing to increased risk of ovarian cancer incidence and mortality following metabolic impairments, including obesity, are not entirely understood. It has been proven that adipose tissue not only serves as calorie storage, but it is also a source of both pro-inflammatory and anti-inflammatory factors, known as adipocytokines. Dysregulation of adipokine and cytokine levels can be derived from excess adipose tissue, alter tissue immune responses, and help in tumor evasion of immune responses (Liu et al., 2015; Preston et al., 2011). On the other hand, since adipose tissue acts as an endocrine organ that integrates various physiological processes, excess adiposity also causes altered endocrine function, leading to major alterations in pro-tumorigenic signal transduction pathways (Vrachnis et al., 2016). The most widely accepted biological mechanisms are discussed as follows:

\section{Adipocytokines}

Cytokines are secreted proteins released by cells, and are involved in chemotaxis and cell growth. Elevated levels of adipocytokines, which are produced in adipose tissue [including IL-5 (Interleukin-5), IL-6, IL-8, IL-10, IL-12, IL-13, leptin, $\mathrm{C}$ reactive protein (CRP), IFNY, monocyte chemotactic protein-1 (MCP-1), and TNF-a (tumor necrosis factor a)] (Schmidt et al., 2015; Wang et al., 2007) and numbers of immune cells (mainly macrophages), as well, have been shown in patients with obesity (Weisberg et al., 2003). It has been indicated that pro-inflammatory cytokine IL- 6 is elevated in the serum of patients with ovarian cancer and it is related to poor outcomes (Lane et al., 2011). IL-6 activates the JAK-STAT3 pathway, and thereby promotes the invasion and metastasis of ovarian cancer cells (Kumar \& Ward, 2014). Besides, IL-6 induces the Mcl-1 anti-apoptotic protein expression, which is recurrently overexpressed in ovarian cancer (Kolomeyevskaya et al., 2015), and it is associated with advanced tumor grade and poor survival in epithelial ovarian cancer (Chen et al., 2013). IL-6 is also accompanied by chemotherapy resistance, further proving the role of this cytokine in ovarian cancer outcomes 
(Gastl \& Plante, 2001). IL-8 and its receptor (CXCR1) are upregulated in ovarian cancer cells and mediate homing, migration, and adhesion of ovarian cancer cells (Nieman et al., 2011). Besides, increased levels of TNF-a, contributes to insulin resistance, and has been associated with tumor grade and poorer survival in epithelial ovarian cancer (Kolomeyevskaya et al., 2015). Higher levels of CRP, as a marker of inflammation, have also been linked with the increased risk of developing ovarian cancer (Braun et al., 2011). There has been a close relationship between leptin, a hormone produced by immature adipocytes, and hormonal regulation of normal ovarian tissue. In addition, leptin is associated with estradiol secretion from the ovaries (Ray et al., 2018). Leptin usually regulates the energy balance of the body, but in obesity, leptin is involved in pro-inflammatory processes (Ray et al., 2018). Notably, the independent predictive value of leptin in combination with other analytes has been shown in ovarian malignancy (Mor et al., 2005). Leptin proliferative effects on ovarian cancer cell lines OVCAR-3 and A2780, after transfection with estrogen receptor- $a$, has also been described (Choi et al., 2011). While serum leptin levels are reduced in patients with ovarian cancer, the expression of leptin and its receptors are upregulated in ovarian cancer tissue (Ray et al., 2018). Overexpression of leptin receptors correlated with worse progression-free survival and contrastingly decreased levels of leptin have been reported with ovarian cancer progression (Kato et al., 2015; Uddin et al., 2009). Besides, inhibition of established tumorigenic effects of leptin via direct inhibition of the PI3K pathway (Choi et al., 2011; Uddin et al., 2009; Hoffmann et al., 2016), which is activated in ovarian cancer cells, has also been demonstrated by numerous studies (Keum et al., 2015; Chen et al., 2013; Hoffmann et al., 2016). Poorer outcomes in epithelial ovarian cancer were correlated with enhanced levels of leptin, as well as the expression of its receptor and the leptin to adiponectin ratio (Kato et al., 2015; Diaz et al., 2013). Leptin has been shown to contribute to metastatic advancement of epithelial ovarian cancer by assisting cell migration and tissue invasion by binding to OB-Rb mediated via JAK/STAT3, MAPK, AKT, mTOR, RhoA/ ROCK, and MYPT1 signaling pathways (Wu et al., 2012). Furthermore, leptin is involved in anti-apoptotic process through inhibition of some apoptosis pathway elements such as TNF receptor 1, caspase-6, caspase-3, and Bad (Ray et al., 2018). Leptin also enhances ovarian cancer progression through conservation of stem cells and mesenchymal characteristics of the cancer cells (Ray et al., 2018).

Adiponectin with insulin-sensitization, antiangiogenic, anti-inflammatory, and anti-neoplastic properties is reduced in obesity (Hada et al., 2007). Despite no correlation between adiponectin levels and progression of ovarian cancer (Jin et al., 2016), reduced serum adiponectin levels have been found in ovarian cancer (Jin et al., 2016; Otokozawa et al., 2015). Adiponectin anti-proliferative effects have mostly contributed to its induced reduction in the bioavailability of proinflammatory factors, performing crucial roles in the cancer-related metabolic syndrome (Booth et al., 2015). In a recent study in ovarian cancer, longer disease-specific survival ( 57 months) has been seen in women with low leptin to adiponectin ratios compared to those with medium or high levels (49 and 37 months, respectively).

Hyperactivation of the fatty acid oxidation pathway was reported in metastatic ovarian cancer cells (Zhu et al., 2019). Activated fatty acid oxidation signaling pathway contributes to the loss of NKX2-8 and reprogramming of fatty acid metabolism of ovarian cancer cells and results in chemoresistance (Zhu et al., 2019).

Relative hypoxia with low oxygen and nutrient availability are enhanced in the increased growth of individual adipocytes and adiposity (Park et al., 2014). Increased expression of leptin, IL-6, and VEGF (vascular endothelial growth factor) and decreased adiponectin have been reported to be caused by hypoxia (Preston et al., 2011). Indeed, this relative hypoxia upregulates the expression of hypoxia-inducible factor (HIF), a transcription factor, to mediate the survival adaptation of cancer cells (Park et al., 2014). HIF increases the expression of inflammatory cytokines (like IL-6, CXCR4), attracting macrophages that release inflammatory factors such as TNF-a and MCP-1 (Park et al., 2014). In epithelial ovarian cancer, upregulated CXCR4 has been shown to be accompanied by elevated recruitment of tumor-associated macrophages, associated with poor prognosis, and production of proangiogenic growth factors (Downs et al., 2002).

The salt-inducible kinases 2 (SIK2), a member of the AMP-activated protein kinase (AMPK) family, is produced specifically in the adipose tissue and plays roles in the modulation of different biological processes such as adipocyte energy metabolism and macrophage signaling pathways (Du et al., 2008). SIK2 enhances inflammation through the downregulation of anti-inflammatory cytokines such as $\mathrm{IL}-10$ and upregulation of inflammatory cytokines such as IL-6, IL-12, TNF-a (Kargbo, 2018). It has been reported that SIK2 expression is elevated in obesity and insulin resistance (Säll et al., 2017). Moreover, SIK2 involves various disorders, especially ovarian cancer, by different proliferative and anti-apoptotic mechanisms (Gao et al., 2020). Hence, it has been proposed that SIK2 is a crucial oncogenic element in human ovarian cancer (Gao et al., 2020). SIK2 enhances the level of HIF-1a through activation of the PI3K/AKT signaling pathway and also activates Drp1 phosphorylation-mediated mitochondrial fission and promotes metabolic reprogramming to switch from oxidative phosphorylation to glycolysis, which is known as Warburg effect, in ovarian cancer cells to supply cellular energy for the progression and metastasis of the cancer cells (Gao et al., 2020). Recently, AMPK has been identified as a crucial energy regulator in ovarian cancer cells (Chen et al., 2019). In other words, ovarian cancer cells provide energy from lipid metabolism through AMPK/ACC/FASN lipogenesis and AMPK/TAK1/NF-KB signaling (Chen et al., 2019).

Secreted protein acidic and rich in cysteine (SPARC or BM-40) is an extracellular matrix protein and has the inhibitory effects on the differentiation of the adipocytes and adipogenesis (Nie \& Sage, 2009). Although the precise roles of SPARC in tumors are not still obvious, dysregulation of this protein has been reported in obesity and diabetes (Kos \& Wilding, 2010; Kos et al., 2009). It has been shown that SPARC-null mice were more likely to be affected by Diet-induced obesity (Nie et al., 2011). This protein has anti-inflammatory properties and tumor suppressor effects in ovarian cancer through inhibition of the metabolic plasticity and mitochondrial bioenergetics; thereby, SPARC inhibits the cancer cell interactions, proliferation, and invasion of ovarian cancer (John et al., 2019; Naczki et al., 2018). It has been suggested that SPARC exerts the tumor suppressor effects in ovarian cancer through inhibition of CEBP $\beta, N F k B, A P-1$, and their downstream inflammatory effects (John et al., 2019).

\section{Hormones}

Hormones such as insulin, IGF-1 (Insulin-like growth factor 1), and IGF-2 are able to activate HIF-1 in conditions of decreased oxygen availability (Park et al., 2014). Cell growth in ovarian cancer cells has been shown to be promoted by IGF-1, which is usually related to obesity and hyperinsulinism (Hursting et al., 2003). The associated increase in IGF-1 and its signaling in obesity and DM is inversely linked with the survival of epithelial ovarian cancer (Spentzos et al., 2007). Furthermore, metabolic 
derangements induce significant changes in sex hormones, which probably play a mechanistic role in ovarian cancer progress (Park et al., 2014). Circulating aromatase-derived estrogen is positively connected to BMI in postmenopausal women (Cowey \& Hardy, 2006), so that every 5 unit increase in BMI leads to a $12.8 \%$ increase in unconjugated estradiol levels (Schairer et al., 2016). Also, circulating levels of estrogen and androgen have been revealed to be increased by obesity mostly in postmenopausal women (McTiernan et al., 2006). Estradiol, probably by promoting the proliferation of ovarian epithelial cells (Cunat et al., 2004), was associated with the endometrioid subtype of ovarian cancer (Schock et al., 2014), which is more likely estrogen and progesterone receptor-positive (Hecht et al., 2009). Additionally, despite the more obvious role of estrogen exposure in uterine carcinogenesis, the contribution of increased estrogen and estrogen signaling in ovarian cancer development has also been documented (Laws et al., 2014). There are also some studies supporting the evidence that ovarian cancer risk may be increased by higher circulating androgen levels (Lukanova et al., 2003; Schock et al., 2014). As such, the higher risk of ovarian cancer in polycystic ovarian syndrome has been documented (Barry et al., 2014; El Hayek et al., 2016). It should be noted that SIK2, which is increased in obesity and related to ovarian cancer, also plays roles in hormonal signal transduction in adipose tissue (Gao et al., 2020; Katoh et al., 2004).

\section{DIABETES MELLITUS AND OVARIAN CANCER}

DM is a frequently detected metabolic disease. The disease features a lack of insulin secretion ability (type 1) and inefficiency in insulin use (type 2) (CDC, 2017). At present, there are over 425 million people diagnosed with DM living in the world. In 2017, more than 727 billion US dollars were spent in facilities associated with DM treatment and healthcare, and such spending has been expected to rise progressively, and it may exceed 800 billion within 25 years in the future (CDC, 2017).

The inflammatory situation and increased number of immune cells in obesity can impair adipose tissue function, causing insulin resistance and type 2 DM, and eventually create a tumorigenic environment (Ray et al., 2018). Several epidemiologic studies and meta-analyses confirmed the theory of the direct effect of DM in elevated risk of colorectal, breast, and endometrial cancers (Vigneri et al., 2009), and they have shown that it is related with poor survival in colon, pancreas, and breast cancers (Coughlin et al., 2004). These consequences appear to be unrelated to obesity (Coughlin et al., 2004), as a recognized risk factor for both the progress of cancer and mortality from it (Calle et al., 2003; Barone et al., 2008; Craig et al., 2016). High serum levels of glucose in DM may be associated with poor prognosis for ovarian cancer and less survival of the patients (Lamkin et al., 2009). Furthermore, triacylglycerol is associated with DM and also the higher risk of serous ovarian tumors (Zeleznik et al., 2020). Hence, disrupted triacylglycerol levels in DM patients may enhance the metastasis of ovarian cancer cells.

\section{MECHANISMS ASSOCIATING DIABETES MEL- LITUS TO OVARIAN CANCER}

The association of DM and cancer is a multipart process. The molecular perspective suggests that elevated IGF-1, increased cytokine and estrogen levels, adipokine imbalances, and hyperinsulinemia contribute to a high risk of malignancy besides leading to poorer patient outcomes (Howe et al., 2013).

The etiological relation of DM and ovarian cancer is not obvious, but there is sufficient biological evidence. Overexpression of IGF-I and -II are demonstrated in various cancers (Gallagher \& LeRoith, 2015; Malaguarnera \& Belfiore, 2014), which may result in elevated proliferation, besides invasion and metastasis pathways (Gallagher \& LeRoith, 2011; Pollak, 2012). Increased levels of IGF-I and -II have been linked with a reduction in ovarian cancer survival (Sayer et al., 2005; Yu \& Rohan, 2000). Furthermore, insulin resistance and DM are associated with low serum sex hormone-binding globulin (Wallace et al., 2013; Ye et al., 2017), which can cause increased free estrogen production. The carcinogenic evidence of high estrogen levels is indubitable in endometrial and ovarian cancer (Laws et al., 2014; Brown \& Hankinson, 2015). An addition, convincing association of DM and cancer progress is through inflammatory pathways. Adipose metabolic dysregulation as a hallmark of DM (Amato et al., 2014), can result in high levels of inflammatory cytokines, including IL-6 and TNF-a (Amato et al., 2014). These cytokines stimulate cell proliferation, invasion, and evasion of antitumor immunity pathways (Yu et al., 2009).

SIK2 is also elevated in DM and plays roles in modulating the insulin-signaling cascade by phosphorylation of Ser-794 of insulin-receptor-substrate-1 (IRS-1) (Säll et al., 2017). TBC1D8, an activated factor of the GTP enzyme, involved in DM (Frasa et al., 2012), participates in ovarian cancer tumorigenesis and metabolic reprogramming (Chen et al., 2019). TBC1D8 is unregulated in the aggressive ovarian cancer cells and it is associated with poor prognosis in these patients (Chen et al., 2019). SPARC, which has anti-inflammatory and inhibitory effects in ovarian cancer cells, is also related to obesity-induced insulin resistance (Harries et al., 2013). Dysregulation of SPARC alters the levels of inflammatory cytokines related to insulin-stimulated glucose transport, glucose transporter 4, and ATP synthesis in mitochondria, and eventually induces insulin resistance (Shen et al., 2014).

It has been stated that the increased level of insulin, which is common in type 2 DM due to insulin resistance, causes leptin overproduction, which in turn, increases leptin concentration, is related to the risk of incidence and progression of endometrial and ovarian cancers (Doucet et al., 2000; Ma et al., 2013; Jin et al., 2016). Moreover, leptin can also lead to vascular VEGF overexpression, a feature of malignant tumor development (Gonzalez-Perez et al., 2010). In addition, hyperinsulinemia enhances the levels of estradiol and testosterone, and thereby leads to poor prognosis in cancer patients (Ruge et al., 2012). On the other hand, insulin may have an anti-apoptotic effect on the cancer cells by alteration in the PI3K/AKT pathway and mitotic kinase pathway (Gryko et al., 2014).

Recently, microRNAs (miRNAs) have been proposed as the molecules, which can be potentially involved in ovarian cancer in obese and diabetic women. MiR-150 is suggested as a miRNA which its deficiency is involved in the obesity-associated inflammation of adipose tissue and the resulting insulin resistance (Ying et al., 2016). Since miR-150 can upregulate glycolysis via targeting AKT3, it may directly reduce the Warburg effect and resistance in ovarian cancer cells (Yu et al., 2019; Wuerkenbieke et al., 2015). Moreover, miR-29b, which is dysregulated in obesity and DM, can also affect the Warburg effect via downregulating AKT2 and AKT3 in ovarian cancer cells (Dooley et al.,2016; Teng et al., 2015). So, miR-29b can negatively affect tumor glucose metabolism and thereby reduce the progression of ovarian cancer (Teng et al., 2015).

Hyperglycemia, as the most noticeable clinical mark of DM, involves tumor development via various pathways leading to increased proliferative, anti-apoptotic, and metastatic cancer activity (Masur et al., 2011; Li et al., 2011). In addition, hyperglycemia may cause endothelial dysfunction, endothelial cell death and aberrant neoangiogenesis (Bhattacharyya et al., 2012; De Mattia et al., 2008). 
Hyperglycemia-associated AGEs (advanced glycation end-products) promote pathological activation of protein kinase $C$, which can cause altered vascular proliferation. The interaction of AGEs with their receptors causes oxidative stress and inflammation, leading to cancer progression (Giorgi et al., 2017; Rojas et al., 2010).

Investigations regarding the effects of metformin proposed an improvement in both cancer risks, along with better survival (Habib \& Rojna, 2013; Martin \& Marais, 2012; Rattan et al., 2012). The metformin mechanism of action is not clear, even though inhibition of the mTOR pathway may participate in the metformin's anti-proliferative effects (Cantrell et al., 2010). There are observational and preclinical studies signifying a valuable influence of metformin on ovarian cancer survival (Dilokthornsakul et al., 2013; Garrido et al., 2018; Kheirandish et al., 2018).

\section{CONCLUSION}

The association between increased risk for developing ovarian cancer and mortality from it with obesity and DM has been highlighted in numerous studies
(Figure 1). Considering the high and growing prevalence of obesity and DM, a comprehensive intervention on these metabolic abnormalities may diminish the worldwide burden from ovarian cancer. The prognostic significance of metabolic abnormalities may have considerable implications because of the feasibility of available interventions. Moreover, due to the lack of enough studies estimating the subtype-specific associations with metabolic abnormalities, supplementary studies are needed to overcome this problem.

\section{CONFLICT OF INTEREST}

The authors declare no conflict of interest.

\section{Corresponding author:}

Maryam Shabani Nashtaei

Department of Anatomy

School of Medicine

Tehran University of Medical Sciences

Tehran, Iran.

E-mail: shabani-m@sina.tums.ac.ir

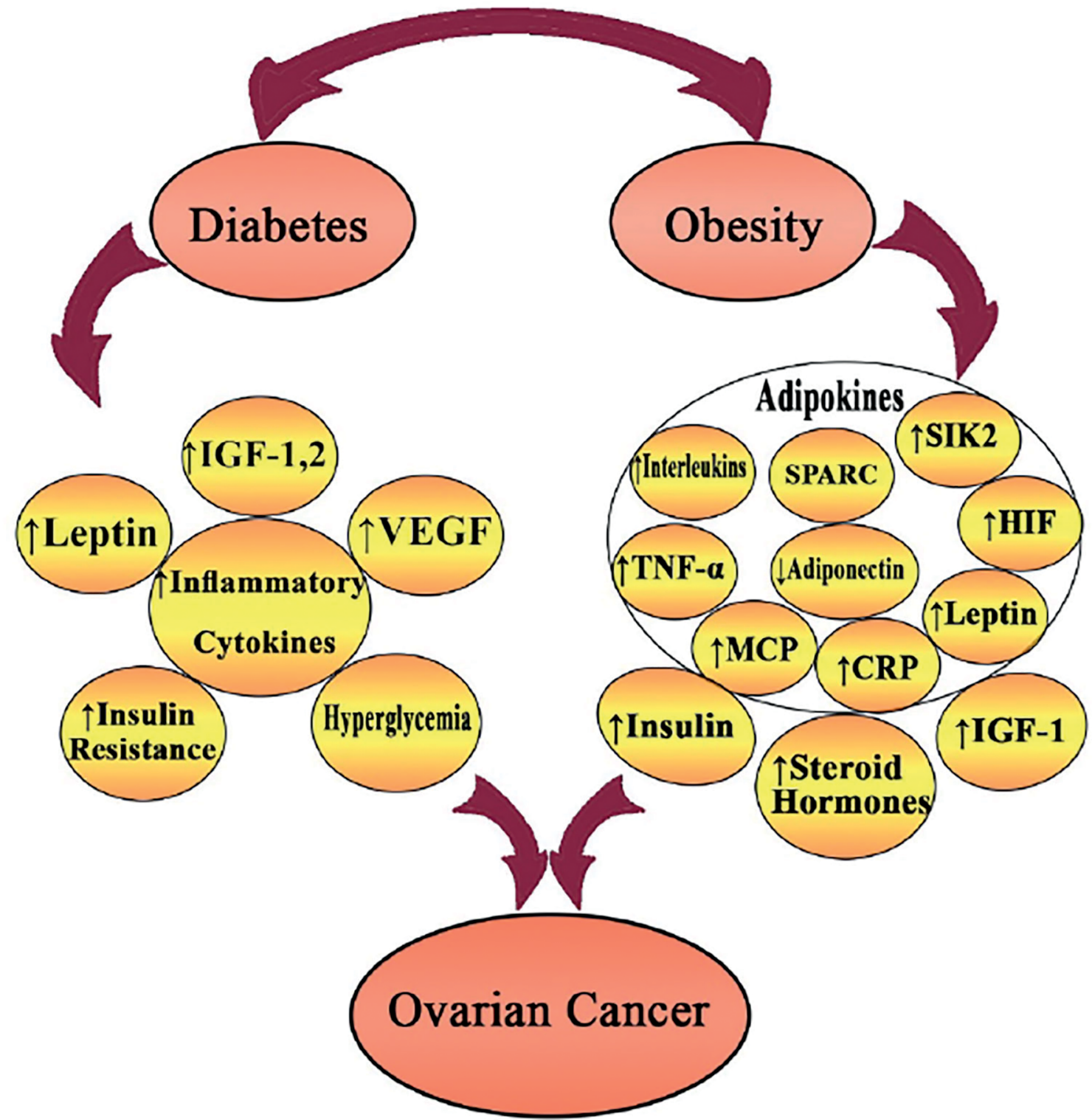

Figure 1. Figure showing the mechanism by which obesity and diabetes affect ovarian cancer. 


\section{REFERENCES}

Al-Sulaiti H, Diboun I, Banu S, Al-Emadi M, Amani P, Harvey TM, Dömling AS, Latiff A, Elrayess MA. Triglyceride profiling in adipose tissues from obese insulin sensitive, insulin resistant and type 2 diabetes mellitus individuals. J Transl Med. 2018;16:175. PMID: 29940972 DOI: 10.1186/ s12967-018-1548-x

Amato MC, Pizzolanti G, Torregrossa V, Misiano G, Milano $\mathrm{S}$, Giordano C. Visceral adiposity index (VAI) is predictive of an altered adipokine profile in patients with type 2 diabetes. PLoS One. 2014;9:e91969. PMID: 24651545 DOI: 10.1371/journal.pone.0091969

Anderson JP, Ross JA, Folsom AR. Anthropometric variables, physical activity, and incidence of ovarian cancer: The Iowa Women's Health Study. Cancer. 2004;100:151521. PMID: 15042687 DOI: 10.1002/cncr.20146

Bae HS, Kim HJ, Hong JH, Lee JK, Lee NW, Song JY. Obesity and epithelial ovarian cancer survival: a systematic review and meta-analysis. J Ovarian Res. 2014;7:41. PMID: 24834130 DOI: $10.1186 / 1757-2215-7-41$

Bakhru A, Buckanovich RJ, Griggs JJ. The impact of diabetes on survival in women with ovarian cancer. Gynecol Oncol. 2011;121:106-11. PMID: 21236474 DOI: 10.1016/j. ygyno.2010.12.329

Baldwin LA, Huang B, Miller RW, Tucker T, Goodrich ST, Podzielinski I, DeSimone CP, Ueland FR, van Nagell JR, Seamon LG. Ten-year relative survival for epithelial ovarian cancer. Obstet Gynecol. 2012;120:612-8. PMID: 22914471 DOI: $10.1097 / A O G .0 b 013 e 318264 f 794$

Barone BB, Yeh HC, Snyder CF, Peairs KS, Stein KB, Derr $\mathrm{RL}$, Wolff $A C$, Brancati FL. Long-term all-cause mortality in cancer patients with preexisting diabetes mellitus: a systematic review and meta-analysis. JAMA. 2008;300:275464. PMID: 19088353 DOI: 10.1001/jama.2008.824

Barrett SV, Paul J, Hay A, Vasey PA, Kaye SB, Glasspool RM; Scottish Gynaecological Cancer Trials Group. Does body mass index affect progression-free or overall survival in patients with ovarian cancer? Results from SCOTROC I trial. Ann Oncol. 2008;19:898-902. PMID: 18272913 DOI: 10.1093/annonc/mdm606

Barry JA, Azizia MM, Hardiman PJ. Risk of endometrial, ovarian and breast cancer in women with polycystic ovary syndrome: a systematic review and meta-analysis. Hum Reprod Update. 2014;20:748-58. PMID: 24688118 DOI: 10.1093/humupd/dmu012

Bhattacharyya S, Sul K, Krukovets I, Nestor C, Li J, Adognravi OS. Novel tissue-specific mechanism of regulation of angiogenesis and cancer growth in response to hyperglycemia. J Am Heart Assoc. 2012;1:e005967. PMID: 23316333 DOI: 10.1161/JAHA.112.005967

Bianchini F, Kaaks R, Vainio $H$. Overweight, obesity, and cancer risk. Lancet Oncol. 2002;3:565-74. PMID: 12217794 DOI: 10.1016/S1470-2045(02)00849-5

Boeing H. Obesity and cancer--the update 2013. Best Pract Res Clin Endocrinol Metab. 2013;27:219-27. PMID: 23731883 DOI: $10.1016 /$ j.beem.2013.04.005
Booth A, Magnuson A, Fouts J, Foster M. Adipose tissue, obesity and adipokines: role in cancer promotion. Horm Mol Biol Clin Investig. 2015;21:57-74. PMID: 25781552 DOI: $10.1515 / \mathrm{hmbci}-2014-0037$

Braun S, Bitton-Worms K, LeRoith D. The link between the metabolic syndrome and cancer. Int J Biol Sci. 2011; 7:100315. PMID: 21912508 DOI: 10.7150/ijbs.7.1003

Brown SB, Hankinson SE. Endogenous estrogens and the risk of breast, endometrial, and ovarian cancers. Steroids. 2015;99:8-10. PMID: 25555473 DOI: 10.1016/j.steroids.2014.12.013

Calle EE, Rodriguez C, Walker-Thurmond K, Thun MJ. Overweight, obesity, and mortality from cancer in a prospectively studied cohort of U.S. adults. N Engl J Med. 2003;348:162538. PMID: 12711737 DOI: $10.1056 /$ NEJMoa021423

Cantrell LA, Zhou C, Mendivil A, Malloy KM, Gehrig PA, BaeJump VL. Metformin is a potent inhibitor of endometrial cancer cell proliferation--implications for a novel treatment strategy. Gynecol Oncol. 2010;116:92-8. PMID: 19822355 DOI: $10.1016 /$ j.ygyno.2009.09.024

CDC - Centers for Disease Control and Prevention. National Diabetes Statistics Report, 2017. Atlanta, GA: Centers for Disease Control and Prevention; 2017. Available at: https://dev.diabetes.org/sites/default/files/2019-06/ cdc-statistics-report-2017.pdf

Chen C, Chang YC, Lan MS, Breslin M. Leptin stimulates ovarian cancer cell growth and inhibits apoptosis by increasing cyclin D1 and MCl-1 expression via the activation of the MEK/ERK1/2 and PI3K/Akt signaling pathways. Int J Oncol. 2013;42:11139. PMID: 23354006 DOI: 10.3892/ijo.2013.1789

Chen M, Sheng XJ, Qin YY, Zhu S, Wu QX, Jia L, Meng N, He YT, Yan GR. TBC1D8 Amplification Drives Tumorigenesis through Metabolism Reprogramming in Ovarian Cancer. Theranostics. 2019;9:676-90. PMID: 30809301 DOI: $10.7150 /$ thno. 30224

Chen RR, Yung MMH, Xuan Y, Zhan S, Leung LL, Liang RR, Leung THY, Yang H, Xu D, Sharma R, Chan KKL, Ngu SF, Ngan HYS, Chan DW. Targeting of lipid metabolism with a metabolic inhibitor cocktail eradicates peritoneal metastases in ovarian cancer cells. Commun Biol. 2019;2:281. PMID: 31372520 DOI: $10.1038 / s 42003-019-0508-1$

Choi JH, Lee KT, Leung PC. Estrogen receptor alpha pathway is involved in leptin-induced ovarian cancer cell growth. Carcinogenesis. 2011;32:589-96. PMID: 21173433 DOI: $10.1093 /$ carcin/bgq276

Collaborative Group on Epidemiological Studies of Ovarian Cancer, Beral V, Doll R, Hermon C, Peto R, Reeves G. Ovarian cancer and oral contraceptives: collaborative reanalysis of data from 45 epidemiological studies including 23,257 women with ovarian cancer and 87,303 controls. Lancet. 2008;371:303-14. PMID: 18294997 DOI: $10.1016 /$ S01406736(08)60167-1

Collaborative Group on Epidemiological Studies of Ovarian Cancer. Ovarian cancer and body size: individual participant meta-analysis including 25,157 women with ovarian cancer from 47 epidemiological studies. PLoS Med. 2012;9:e1001200. PMID: 22606070 DOI: 10.1371/journal.pmed.1001200 
Craig ER, Londoño AI, Norian LA, Arend RC. Metabolic risk factors and mechanisms of disease in epithelial ovarian cancer: A review. Gynecol Oncol. 2016;143:674-83. PMID: 27751590 DOI: $10.1016 /$ j.ygyno.2016.10.005

Colvin EK. Tumor-associated macrophages contribute to tumor progression in ovarian cancer. Front Oncol. 2014;4:137. PMID: 24936477 DOI: 10.3389/ fonc. 2014.00137

Coughlin SS, Calle EE, Teras LR, Petrelli J, Thun MJ. Diabetes mellitus as a predictor of cancer mortality in a large cohort of US adults. Am J Epidemiol. 2004;159:1160-7. PMID: 15191933 DOI: 10.1093/aje/kwh161

Cowey S, Hardy RW. The metabolic syndrome: A high-risk state for cancer? Am J Pathol. 2006;169:1505-22. PMID: 17071576 DOI: 10.2353/ajpath.2006.051090

Cunat S, Hoffmann P, Pujol P. Estrogens and epithelial ovarian cancer. Gynecol Oncol. 2004;94:25-32. PMID: 15262115 DOI: $10.1016 /$ j.ygyno.2004.03.026

Dal Maso L, Franceschi S, Negri E, Conti E, Montella M, Vaccarella S, Canzonieri V, Parazzini F, La Vecchia C. Body size indices at different ages and epithelial ovarian cancer risk. Eur J Cancer. 2002;38:1769-74. PMID: 12175694 DOI: $10.1016 /$ S0959-8049(02)00155-7

Danaei G, Finucane MM, Lu Y, Singh GM, Cowan MJ, Paciorek CJ, Lin JK, Farzadfar $F$, Khang YH, Stevens GA, Rao M, Ali MK, Riley LM, Robinson CA, Ezzati M; Global Burden of Metabolic Risk Factors of Chronic Diseases Collaborating Group (Blood Glucose). National, regional, and global trends in fasting plasma glucose and diabetes prevalence since 1980: systematic analysis of health examination surveys and epidemiological studies with 370 country-years and 2.7 million participants. Lancet. 2011;378:31-40. PMID: 21705069 DOI: 10.1016/S0140-6736(11)60679-X

De Mattia G, Bravi MC, Laurenti O, Moretti A, Cipriani R, Gatti A, Mandosi $E$, Morano S. Endothelial dysfunction and oxidative stress in type 1 and type 2 diabetic patients without clinical macrovascular complications. Diabetes Res Clin Pract. 2008;79:337-42. PMID: 17949845 DOI: 10.1016/j. diabres.2007.09.005

Diaz ES, Karlan BY, Li AJ. Obesity-associated adipokines correlate with survival in epithelial ovarian cancer. Gynecol Oncol. 2013;129:353-7. PMID: 23402904 DOI: 10.1016/j. ygyno.2013.02.006

Dilokthornsakul $\mathrm{P}$, Chaiyakunapruk N, Termrungruanglert W, Pratoomsoot C, Saokaew S, Sruamsiri R. The effects of metformin on ovarian cancer: a systematic review. Int J Gynecol Cancer. 2013;23:1544-51. PMID: 24172091 DOI: 10.1097/IGC.0b013e3182a80a21

Dixon SC, Nagle CM, Thrift AP, Pharoah PD, Pearce $C L$, Zheng W, Painter JN; AOCS Group \& Australian Cancer Study (Ovarian Cancer), Chenevix-Trench G, Fasching PA, Beckmann MW, Lambrechts D, Vergote I, Lambrechts S, Van Nieuwenhuysen E, Rossing MA, Doherty JA, Wicklund KG, Chang-Claude J, Rudolph A, et al.; Ovarian Cancer Association Consortium. Adult body mass index and risk of ovarian cancer by subtype: a Mendelian randomization study. Int J Epidemiol. 2016;45:884-95. PMID: 27401727 DOI: $10.1093 / \mathrm{ije} /$ dyw158
Dooley J, Garcia-Perez JE, Sreenivasan J, Schlenner SM, Vangoitsenhoven R, Papadopoulou AS, Tian L, Schonefeldt S, Serneels L, Deroose C, Staats KA, Van der Schueren B, De Strooper B, McGuinness OP, Mathieu C, Liston A. The microRNA-29 Family Dictates the Balance Between Homeostatic and Pathological Glucose Handling in Diabetes and Obesity. Diabetes. 2016;65:53-61. PMID: 26696639 DOI: $10.2337 / \mathrm{db} 15-0770$

Doucet $E$, St-Pierre $S$, Alméras $N$, Mauriège $P$, Després JP, Richard D, Bouchard C, Tremblay A; Quebec Family Study. Fasting insulin levels influence plasma leptin levels independently from the contribution of adiposity: evidence from both a cross-sectional and an intervention study. J Clin Endocrinol Metab. 2000;85:4231-7. PMID: 11095459 DOI: $10.1210 /$ jcem.85.11.6980

Downs SM, Hudson ER, Hardie DG. A potential role for AMP-activated protein kinase in meiotic induction in mouse oocytes. Dev Biol. 2002;245:200-12. PMID: 11969266 DOI: $10.1006 /$ dbio.2002.0613

Du J, Chen Q, Takemori H, Xu H. SIK2 can be activated by deprivation of nutrition and it inhibits expression of lipogenic genes in adipocytes. Obesity (Silver Spring). 2008;16:531-8. PMID: 18239551 DOI: 10.1038/oby.2007.98

El Hayek S, Bitar L, Hamdar LH, Mirza FG, Daoud G. Poly Cystic Ovarian Syndrome: An Updated Overview. Front Physiol. 2016;7:124. PMID: 27092084 DOI: 10.3389/ fphys.2016.00124

Engeland A, Tretli S, Bjørge T. Height, body mass index, and ovarian cancer: a follow-up of 1.1 million Norwegian women. J Natl Cancer Inst. 2003;95:1244-8. PMID: 12928351 DOI: $10.1093 /$ jnci/djg010

Fairfield KM, Willett WC, Rosner BA, Manson JE, Speizer FE, Hankinson SE. Obesity, weight gain, and ovarian cancer. Obstet Gynecol. 2002;100:288-96. PMID: 12151152 DOI: $10.1016 / \mathrm{s} 0029-7844(02) 02053-7$

Ferlay J, Soerjomataram I, Dikshit R, Eser S, Mathers C, Rebelo M, Parkin DM, Forman D, Bray F. Cancer incidence and mortality worldwide: sources, methods and major patterns in GLOBOCAN 2012. Int J Cancer. 2015;136:E35986. PMID: 25220842 DOI: $10.1002 /$ ijc. 29210

Fortner RT, Poole EM, Wentzensen NA, Trabert B, White E, Arslan AA, Patel AV, Setiawan VW, Visvanathan $K$, Weiderpass E, Adami HO, Black A, Bernstein L, Brinton LA, Buring J, Clendenen TV, Fournier A, Fraser G, Gapstur SM, Gaudet $\mathrm{MM}$, et al. Ovarian cancer risk factors by tumor aggressiveness: An analysis from the Ovarian Cancer Cohort Consortium. Int J Cancer. 2019;145:58-69. PMID: 30561796 DOI: $10.1002 /$ ijc. 32075

Fotopoulou C, Richter R, Braicu EI, Kuhberg M, Feldheiser A, Schefold JC, Lichtenegger W, Sehouli J. Impact of obesity on operative morbidity and clinical outcome in primary epithelial ovarian cancer after optimal primary tumor debulking. Ann Surg Oncol. 2011;18:2629-37. PMID: 21394662 DOI: 10.1245/s10434-011-1637-z

Frasa MA, Koessmeier KT, Ahmadian MR, Braga VM. Illuminating the functional and structural repertoire of human TBC/RABGAPs. Nat Rev Mol Cell Biol. 2012;13:67-73. PMID: 22251903 DOI: $10.1038 / \mathrm{nrm} 3267$ 
Gallagher EJ, LeRoith D. Minireview: IGF, Insulin, and Cancer. Endocrinology. 2011; 152:2546-51. PMID: 21540285 DOI: $10.1210 /$ en.2011-0231

Gallagher EJ, LeRoith D. Obesity and Diabetes: The Increased Risk of Cancer and Cancer-Related Mortality. Physiol Rev. 2015;95:727-48. PMID: 26084689 DOI: 10.1152/physrev.00030.2014

Gao T, Zhang $X$, Zhao J, Zhou F, Wang $Y$, Zhao Z, Xing J, Chen B, Li J, Liu S. SIK2 promotes reprogramming of glucose metabolism through PI3K/AKT/HIF-1a pathway and Drp1-mediated mitochondrial fission in ovarian cancer. Cancer Lett. 2020;469:89-101. PMID: 31639424 DOI: $10.1016 /$ j.canlet.2019.10.029

Garrido MP, Vera C, Vega M, Quest AFG, Romero C. Metformin prevents nerve growth factor-dependent proliferative and proangiogenic effects in epithelial ovarian cancer cells and endothelial cells. Ther Adv Med Oncol. 2018;10:1758835918770984. PMID: 29774060 DOI: $10.1177 / 1758835918770984$

Gastl G, Plante M. Bioactive interleukin-6 levels in serum and ascites as a prognostic factor in patients with epithelial ovarian cancer. Methods Mol Med. 2001;39:121-3. PMID: 21340762 DOI: 10.1385/1-59259-071-3:121

Giorgi A, Tempera I, Napoletani G, Drovandi D, Potestà C, Martire S, Mandosi E, Filardi T, Eugenia Schininà M, Morano $S$, d'Erme M, Maras B. Poly(ADP-ribosylated) proteins in mononuclear cells from patients with type 2 diabetes identified by proteomic studies. Acta Diabetol. 2017;54:83342. PMID: 28608282 DOI: 10.1007/s00592-017-1013-y

Gonzalez-Perez RR, Xu Y, Guo S, Watters A, Zhou W, Leibovich SJ. Leptin upregulates VEGF in breast cancer via canonic and non-canonical signalling pathways and NFkappaB/HIF-1alpha activation. Cell Signal. 2010;22:1350-62. PMID: 20466060 DOI: $10.1016 / j$.cellsig.2010.05.003

Griggs JJ, Mangu PB, Temin S, Lyman GH. Appropriate Chemotherapy Dosing for Obese Adult Patients With Cancer: American Society of Clinical Oncology Clinical Practice Guideline. J Oncol Pract. 2012;8:e59-e61. PMID: 29452546 DOI: $10.1200 /$ JOP.2012.000623

Gryko M, Kiśluk J, Cepowicz D, Zińczuk J, Kamocki Z, Guzińska-Ustymowicz K, Pryczynicz A, Czyżewska J, Kemona $A$, Kędra B. Expression of insulin-like growth factor receptor type 1 correlate with lymphatic metastases in human gastric cancer. Pol J Pathol. 2014;65:135-40. PMID: 25119174 DOI: $10.5114 /$ pjp.2014.42678

Habib SL, Rojna M. Diabetes and risk of cancer. ISRN Oncol. 2013;2013:583786. PMID: 23476808 DOI: $10.1155 / 2013 / 583786$

Hada Y, Yamauchi T, Waki $H$, Tsuchida A, Hara K, Yago $\mathrm{H}$, Miyazaki $\mathrm{O}$, Ebinuma $\mathrm{H}$, Kadowaki T. Selective purification and characterization of adiponectin multimer species from human plasma. Biochem Biophys Res Commun. 2007;356:487-93. PMID: 17368570 DOI: 10.1016/j. bbrc.2007.03.004

Han CY, Patten DA, Richardson RB, Harper ME, Tsang BK. Tumor metabolism regulating chemosensitivity in ovarian cancer. Genes Cancer. 2018;9:155-75. PMID: 30603053 DOI: $10.18632 /$ genesandcancer. 176
Harries LW, McCulloch LJ, Holley JE, Rawling TJ, Welters HJ, Kos K. A role for SPARC in the moderation of human insulin secretion. PLoS One. 2013;8:e68253. PMID: 23840838 DOI: $10.1371 /$ journal.pone.0068253

Hecht JL, Kotsopoulos J, Hankinson SE, Tworoger SS. Relationship between epidemiologic risk factors and hormone receptor expression in ovarian cancer: results from the Nurses' Health Study. Cancer Epidemiol Biomarkers Prev. 2009;18:1624-30. PMID: 19383883 DOI: 10.1158/10559965.EPI-08-1214

Hoffmann M, Fiedor E, Ptak A. 17ß-Estradiol Reverses Leptin-Inducing Ovarian Cancer Cell Migration by the PI3K/Akt Signaling Pathway. Reprod Sci. 2016;23:1600-8. PMID: 27255147 DOI: $10.1177 / 1933719116648214$

Horowitz NS, Wright AA. Impact of obesity on chemotherapy management and outcomes in women with gynecologic malignancies. Gynecol Oncol. 2015;138:201-6. PMID: 25870918 DOI: $10.1016 /$ j.ygyno.2015.04.002

Howe LR, Subbaramaiah K, Hudis CA, Dannenberg AJ. Molecular pathways: adipose inflammation as a mediator of obesity-associated cancer. Clin Cancer Res. 2013;19:6074-83. PMID: 23958744 DOI: 10.1158/1078-0432.CCR-12-2603

Howlader N, Noone AM, Krapcho M, Neyman N, Aminou $\mathrm{R}$, Waldron W, Altekruse SF, Kosary CL, Ruhl J, Tatalovich $Z$, Cho $H$, Mariotto A, Eisner MP, Lewis DR, Chen HS, Feuer EJ, Cronin KA, Edwards BK, eds. SEER Cancer Statistics Review, 1975-2008. Bethesda, MD: National Cancer Institute; 2011. Available at: https://seer.cancer.gov/ csr/1975_2008/

Hursting SD, Lavigne JA, Berrigan D, Perkins SN, Barrett JC. Calorie restriction, aging, and cancer prevention: mechanisms of action and applicability to humans. Annu Rev Med. 2003;54:131-52. PMID: 12525670 DOI: 10.1146/annurev.med.54.101601.152156

Iglay K, Hannachi $\mathrm{H}$, Joseph Howie $\mathrm{P}, \mathrm{Xu} J$, Li X, Engel SS, Moore LM, Rajpathak S. Prevalence and co-prevalence of comorbidities among patients with type 2 diabetes mellitus. Curr Med Res Opin. 2016;32:1243-52. PMID: 26986190 DOI: $10.1185 / 03007995.2016 .1168291$

Jin JH, Kim HJ, Kim CY, Kim YH, Ju W, Kim SC. Association of plasma adiponectin and leptin levels with the development and progression of ovarian cancer. Obstet Gynecol Sci. 2016;59:27985. PMID: 27462594 DOI: 10.5468/ogs.2016.59.4.279

John B, Naczki C, Patel C, Ghoneum A, Qasem S, Salih Z, Said N. Regulation of the bi-directional cross-talk between ovarian cancer cells and adipocytes by SPARC. Oncogene. 2019;38:4366-83. PMID: 30765860 DOI: 10.1038/ s41388-019-0728-3

Kargbo RB. Kinase Inhibitors for Treatment of Cancer and Inflammation. ACS Med Chem Lett. 2018;9:1073-4. PMID: 30429947 DOI: 10.1021/acsmedchemlett.8b00481

Kato S, Abarzua-Catalan L, Trigo C, Delpiano A, Sanhueza C, García K, Ibañez C, Hormazábal K, Diaz D, Brañes J, Castellón E, Bravo E, Owen G, Cuello MA. Leptin stimulates migration and invasion and maintains cancer stem-like properties in ovarian cancer cells: an explanation for poor outcomes in obese women. Oncotarget. 2015;6:2110019. PMID: 26053184 DOI: $10.18632 /$ oncotarget. 4228 
Katoh Y, Takemori H, Horike N, Doi J, Muraoka M, Min L, Okamoto M. Salt-inducible kinase (SIK) isoforms: their involvement in steroidogenesis and adipogenesis. Mol Cell Endocrinol. 2004;217:109-12. PMID: 15134808 DOI: 10.1016/j.mce.2003.10.016

Keum N, Greenwood DC, Lee DH, Kim R, Aune D, Ju W, Hu FB, Giovannucci EL. Adult weight gain and adiposity-related cancers: a dose-response meta-analysis of prospective observational studies. J Natl Cancer Inst. 2015;107:djv088. PMID: 25757865 DOI: 10.1093/jnci/djv088

Kheirandish M, Mahboobi H, Yazdanparast M, Kamal W, Kamal MA. Anti-cancer Effects of Metformin: Recent Evidences for its Role in Prevention and Treatment of Cancer. Curr Drug Metab. 2018;19:793-7. PMID: 29663879 DOI: 10.21 74/1389200219666180416161846

Kim DJ. The epidemiology of diabetes in Korea. Diabetes Metab J. 2011;35:303-8. PMID: 21977448 DOI: 10.4093/ dmj.2011.35.4.303

Kolomeyevskaya N, Eng KH, Khan AN, Grzankowski KS, Singel KL, Moysich K, Segal BH. Cytokine profiling of ascites at primary surgery identifies an interaction of tumor necrosis factor-a and interleukin- 6 in predicting reduced progression-free survival in epithelial ovarian cancer. Gynecol Oncol. 2015;138:352-7. PMID: 26001328 DOI: 10.1016/j.ygyno.2015.05.009

Kos K, Wong S, Tan B, Gummesson A, Jernas M, Franck N, Kerrigan D, Nystrom FH, Carlsson LM, Randeva HS, Pinkney JH, Wilding JP. Regulation of the fibrosis and angiogenesis promoter SPARC/osteonectin in human adipose tissue by weight change, leptin, insulin, and glucose. Diabetes. 2009;58:1780-8. PMID: 19509023 DOI: $10.2337 / d b 09-$ 0211

Kos K, Wilding JP. SPARC: a key player in the pathologies associated with obesity and diabetes. Nat Rev Endocrinol. 2010;6:225-35. PMID: 20195270 DOI: 10.1038/nrendo. 2010.18

Kumar J, Ward AC. Role of the interleukin 6 receptor family in epithelial ovarian cancer and its clinical implications. Biochim Biophys Acta. 2014;1845:117-25. PMID: 24388871 DOI: $10.1016 /$ j.bbcan.2013.12.003

Kurman RJ, Shih IeM. Pathogenesis of ovarian cancer: lessons from morphology and molecular biology and their clinical implications. Int J Gynecol Pathol. 2008;27:151-60. PMID: 18317228 DOI: 10.1097/PGP.0b013e318161e4f5

Lamkin DM, Spitz DR, Shahzad MM, Zimmerman B, Lenihan DJ, Degeest K, Lubaroff DM, Shinn EH, Sood AK, Lutgendorf SK. Glucose as a prognostic factor in ovarian carcinoma. Cancer. 2009;115:1021-7. PMID: 19156916 DOI: 10.1002/cncr.24126

Lane D, Matte I, Rancourt C, Piché A. Prognostic significance of IL- 6 and IL-8 ascites levels in ovarian cancer patients. BMC Cancer. 2011;11:210. PMID: 21619709 DOI: 10.1186/1471-2407-11-210

Lauby-Secretan B, Scoccianti C, Loomis D, Grosse Y, Bianchini $F$, Straif K; International Agency for Research on Cancer Handbook Working Group. Body Fatness and Cancer--Viewpoint of the IARC Working Group. N Engl J Med. 2016;375:794-8. PMID: 27557308 DOI: 10.1056/NEJMsr1606602
Laws MJ, Kannan A, Pawar S, Haschek WM, Bagchi MK, Bagchi IC. Dysregulated estrogen receptor signaling in the hypothalamic-pituitary-ovarian axis leads to ovarian epithelial tumorigenesis in mice. PLoS Genet. 2014;10:e1004230. PMID: 24603706 DOI: 10.1371/journal.pgen.1004230

Lee JY, Jeon I, Kim JW, Song YS, Yoon JM, Park SM. Diabetes mellitus and ovarian cancer risk: a systematic review and meta-analysis of observational studies. Int J Gynecol Cancer. 2013;23:402-12. PMID: 23354371 DOI: 10.1097/ IGC.0b013e31828189b2

Leitzmann MF, Koebnick C, Danforth KN, Brinton LA, Moore SC, Hollenbeck AR, Schatzkin A, Lacey JV Jr. Body mass index and risk of ovarian cancer. Cancer. 2009;115:81222. PMID: 19127552 DOI: $10.1002 /$ cncr. 24086

Liu Y, Metzinger MN, Lewellen KA, Cripps SN, Carey KD, Harper EI, Shi Z, Tarwater L, Grisoli A, Lee E, Slusarz A, Yang J, Loughran EA, Conley K, Johnson JJ, Klymenko Y, Bruney L, Liang Z, Dovichi NJ, Cheatham B, et al. Obesity Contributes to Ovarian Cancer Metastatic Success through Increased Lipogenesis, Enhanced Vascularity, and Decreased Infiltration of M1 Macrophages. Cancer Res. 2015;75:5046-57. PMID: 26573796 DOI: 10.1158/0008-5472.CAN-15-0706

Liu Z, Zhang TT, Zhao JJ, Qi SF, Du P, Liu DW, Tian QB. The association between overweight, obesity and ovarian cancer: a meta-analysis. Jpn J Clin Oncol. 2015;45:1107-15. PMID: 26491203 DOI: $10.1093 /$ jjco/hyv150

Li W, Ma Q, Li J, Guo K, Liu H, Han L, Ma G. Hyperglycemia enhances the invasive and migratory activity of pancreatic cancer cells via hydrogen peroxide. Oncol Rep. 2011;25:1279-87. PMID: 21249318 DOI: 10.3892/ or. 2011.1150

Lukanova A, Lundin E, Akhmedkhanov A, Micheli A, Rinaldi S, Zeleniuch-Jacquotte A, Lenner P, Muti P, Biessy C, Krogh V, Berrino F, Hallmans G, Riboli E, Kaaks R, Toniolo P. Circulating levels of sex steroid hormones and risk of ovarian cancer. Int J Cancer. 2003;104:636-42. PMID: 12594820 DOI: $10.1002 / \mathrm{ijc} .10990$

Lubin F, Chetrit A, Freedman LS, Alfandary E, Fishler $Y$, Nitzan $\mathrm{H}$, Zultan A, Modan B. Body mass index at age 18 years and during adult life and ovarian cancer risk. Am J Epidemiol. 2003;157:113-20. PMID: 12522018 DOI: 10.1093/aje/kwf184

Ma Y, Liu Z, Zhang Y, Lu B. Serum leptin, adiponectin and endometrial cancer risk in Chinese women. J Gynecol Oncol. 2013;24:336-41. PMID: 24167669 DOI: 10.3802/ jgo.2013.24.4.336

Malaguarnera R, Belfiore A. The emerging role of insulin and insulin-like growth factor signaling in cancer stem cells. Front Endocrinol (Lausanne). 2014;5:10. PMID: 24550888 DOI: $10.3389 /$ fendo.2014.00010

Martin M, Marais R. Metformin: a diabetes drug for cancer, or a cancer drug for diabetics? J Clin Oncol. 2012;30:2698700. PMID: 22565000 DOI: 10.1200/JCO.2012.42.1677

Masur K, Vetter C, Hinz A, Tomas N, Henrich H, Niggemann B, Zänker KS. Diabetogenic glucose and insulin concentrations modulate transcriptome and protein levels involved in tumour cell migration, adhesion and proliferation. Br J Cancer. 2011;104:345-52. PMID: 21179032 DOI: $10.1038 /$ sj.bjc. 6606050 
Mayne ST, Playdon MC, Rock CL. Diet, nutrition, and cancer: past, present and future. Nat Rev Clin Oncol. 2016;13:504-15. PMID: 26951041 DOI: 10.1038/nrclinonc. 2016.24

McTiernan A, Wu L, Chen C, Chlebowski R, Mossavar-Rahmani $Y$, Modugno F, Perri MG, Stanczyk FZ, Van Horn L, Wang CY; Women's Health Initiative Investigators. Relation of BMI and physical activity to sex hormones in postmenopausal women. Obesity (Silver Spring). 2006;14:1662-77. PMID: 17030978 DOI: 10.1038/oby.2006.191

Mor G, Visintin I, Lai $Y$, Zhao H, Schwartz P, Rutherford T, Yue L, Bray-Ward P, Ward DC. Serum protein markers for early detection of ovarian cancer. Proc Natl Acad Sci U S A. 2005;102:7677-82. PMID: 15890779 DOI: 10.1073/ pnas. 0502178102

Munir R, Lisec J, Swinnen JV, Zaidi N. Lipid metabolism in cancer cells under metabolic stress. $\mathrm{Br} \mathrm{J}$ Cancer. 2019;120:1090-8. PMID: 31092908 DOI: 10.1038/ s41416-019-0451-4

Naczki C, John B, Patel C, Lafferty A, Ghoneum A, Afify $H$, White M, Davis A, Jin G, Kridel S, Said N. SPARC Inhibits Metabolic Plasticity in Ovarian Cancer. Cancers (Basel). 2018;10:385. PMID: 30332737 DOI: 10.3390/cancers 10100385

Nagle CM, Dixon SC, Jensen A, Kjaer SK, Modugno F, deFazio A, Fereday S, Hung J, Johnatty SE; Australian Ovarian Cancer Study Group, Fasching PA, Beckmann MW, Lambrechts $D$, Vergote I, Van Nieuwenhuysen $E$, Lambrechts S, Risch HA, Rossing MA, Doherty JA, Wicklund KG, et al.; Ovarian Cancer Association Consortium. Obesity and survival among women with ovarian cancer: results from the Ovarian Cancer Association Consortium. $\mathrm{Br}$ J Cancer. 2015;113:817-26. PMID: 26151456 DOI: 10.1038/ bjc. 2015.245

NCD-RisC. NCD Risk Factor Collaboration. Trends in adult body-mass index in 200 countries from 1975 to 2014: a pooled analysis of 1698 population-based measurement studies with 19.2 million participants. Lancet. 2016;387:1377-96. PMID: 27115820 DOI: 10.1016/ S0140-6736(16)30054-X

Nie J, Sage EH. SPARC functions as an inhibitor of adipogenesis. J Cell Commun Signal. 2009;3:247-54. PMID: 19798596 DOI: $10.1007 /$ s12079-009-0064-4

Nie J, Bradshaw AD, Delany AM, Sage EH. Inactivation of SPARC enhances high-fat diet-induced obesity in mice. Connect Tissue Res. 2011;52:99-108. PMID: 20615096 DOI: $10.3109 / 03008207.2010 .483747$

Nieman KM, Kenny HA, Penicka CV, Ladanyi A, Buell-Gutbrod R, Zillhardt MR, Romero IL, Carey MS, Mills GB, Hotamisligil GS, Yamada SD, Peter ME, Gwin K, Lengyel E. Adipocytes promote ovarian cancer metastasis and provide energy for rapid tumor growth. Nat Med. 2011;17:1498503. PMID: 22037646 DOI: $10.1038 / \mathrm{nm} .2492$

Olsen CM, Green AC, Whiteman DC, Sadeghi S, Kolahdooz F, Webb PM. Obesity and the risk of epithelial ovarian cancer: a systematic review and meta-analysis. Eur J Cancer. 2007;43:690709. PMID: 17223544 DOI: 10.1016/j.ejca.2006.11.010
Olsen CM, Nagle CM, Whiteman DC, Purdie DM, Green AC, Webb PM. Body size and risk of epithelial ovarian and related cancers: a population-based case-control study. Int J Cancer. 2008;123:450-6. PMID: 18449887 DOI: 10.1002/ ijc. 23509

Olsen CM, Nagle CM, Whiteman DC, Ness R, Pearce CL, Pike MC, Rossing MA, Terry KL, Wu AH; Australian Cancer Study (Ovarian Cancer); Australian Ovarian Cancer Study Group, Risch HA, Yu H, Doherty JA, Chang-Claude J, Hein R, Nickels S, Wang-Gohrke S, Goodman MT, Carney ME, et al.; Ovarian Cancer Association Consortium. Obesity and risk of ovarian cancer subtypes: evidence from the Ovarian Cancer Association Consortium. Endocr Relat Cancer. 2013;20:251-62. PMID: 23404857 DOI: 10.1530/ERC-120395

Oshakbayev KP, Alibek K, Ponomarev IO, Uderbayev NN, Dukenbayeva BA. Weight change therapy as a potential treatment for end-stage ovarian carcinoma. Am J Case Rep. 2014;15:203-11. PMID: 24847411 DOI: 10.12659/ AJCR.890229

Otokozawa S, Tanaka R, Akasaka H, Ito E, Asakura S, Ohnishi H, Saito S, Miura T, Saito T, Mori M. Associations of Serum Isoflavone, Adiponectin and Insulin Levels with Risk for Epithelial Ovarian Cancer: Results of a Case-control Study. Asian Pac J Cancer Prev. 2015;16:4987-91. PMID: 26163627 DOI: 10.7314/APJCP.2015.16.12.4987

Park J, Morley TS, Kim M, Clegg DJ, Scherer PE. Obesity and cancer--mechanisms underlying tumour progression and recurrence. Nat Rev Endocrinol. 2014;10:455-65. PMID: 24935119 DOI: 10.1038/nrendo.2014.94

Pavelka JC, Brown RS, Karlan BY, Cass I, Leuchter RS, Lagasse LD, Li AJ. Effect of obesity on survival in epithelial ovarian cancer. Cancer. 2006;107:1520-4. PMID: 16941453 DOI: $10.1002 /$ cncr. 22194

Pennington KP, Swisher EM. Hereditary ovarian cancer: beyond the usual suspects. Gynecol Oncol. 2012;124:34753. PMID: 22264603 DOI: 10.1016/j.ygyno.2011.12.415

Pollak M. The insulin and insulin-like growth factor receptor family in neoplasia: an update. Nat Rev Cancer. 2012;12:159-69. PMID: 22337149 DOI: $10.1038 /$ nrc3215

Poole EM, Konstantinopoulos PA, Terry KL. Prognostic implications of reproductive and lifestyle factors in ovarian cancer. Gynecol Oncol. 2016;142:574-87. PMID: 27189457 DOI: $10.1016 /$ j.ygyno.2016.05.014

Poorolajal J, Jenabi E, Masoumi SZ. Body mass index effects on risk of ovarian cancer: a meta-analysis. Asian Pac J Cancer Prev. 2014;15:7665-71. PMID: 25292044 DOI: 10.7314/APJCP.2014.15.18.7665

Preston CC, Goode EL, Hartmann LC, Kalli KR, Knutson $\mathrm{KL}$. Immunity and immune suppression in human ovarian cancer. Immunotherapy. 2011;3:539-56. PMID: 21463194 DOI: $10.2217 /$ imt. 11.20

Protani MM, Nagle CM, Webb PM. Obesity and ovarian cancer survival: a systematic review and meta-analysis. Cancer Prev Res (Phila). 2012;5:901-10. PMID: 22609763 DOI: $10.1158 / 1940-6207 . C A P R-12-0048$ 
Rattan R, Ali Fehmi R, Munkarah A. Metformin: an emerging new therapeutic option for targeting cancer stem cells and metastasis. J Oncol. 2012;2012:928127. PMID: 22701483 DOI: $10.1155 / 2012 / 928127$

Ray A, Fornsaglio J, Dogan S, Hedau S, Naik D, De A. Gynaecological cancers and leptin: A focus on the endometrium and ovary. Facts Views Vis Obgyn. 2018;10:5-18. PMID: 30510663

Renehan AG, Tyson M, Egger M, Heller RF, Zwahlen $M$. Body-mass index and incidence of cancer: a systematic review and meta-analysis of prospective observational studies. Lancet. 2008;371:569-78. PMID: 18280327 DOI: $0.1016 / S 0140-6736(08) 60269-X$

Reeves GK, Pirie K, Beral V, Green J, Spencer E, Bull D; Million Women Study Collaboration. Cancer incidence and mortality in relation to body mass index in the Million Women Study: cohort study. BMJ. 2007;335:1134. PMID: 17986716 DOI: $10.1136 / \mathrm{bmj} .39367 .495995 . \mathrm{AE}$

Rodriguez C, Calle EE, Fakhrabadi-Shokoohi D, Jacobs EJ, Thun MJ. Body mass index, height, and the risk of ovarian cancer mortality in a prospective cohort of postmenopausal women. Cancer Epidemiol Biomarkers Prev. 2002;11:8228.

Rojas A, Figueroa $\mathrm{H}$, Morales E. Fueling inflammation at tumor microenvironment: the role of multiligand/RAGE axis. Carcinogenesis. 2010;31:334-41. PMID: 20028726 DOI: $10.1093 /$ carcin/bgp322

Ruge T, Sukonina V, Kroupa O, Makoveichuk E, Lundgren M, Svensson MK, Olivecrona G, Eriksson JW. Effects of hyperinsulinemia on lipoprotein lipase, angiopoietin-like protein 4, and glycosylphosphatidylinositol-anchored high-density lipoprotein binding protein 1 in subjects with and without type 2 diabetes mellitus. Metabolism. 2012;61:652-60. PMID: 22078753 DOI: 10.1016/j.metabol.2011.09.014

Säll J, Pettersson AM, Björk C, Henriksson E, Wasserstrom $S$, Linder $W$, Zhou $Y$, Hansson $O$, Andersson DP, Ekelund M, Degerman E, Stenkula KG, Laurencikiene J, Göransson 0 . Salt-inducible kinase 2 and -3 are downregulated in adipose tissue from obese or insulin-resistant individuals: implications for insulin signalling and glucose uptake in human adipocytes. Diabetologia. 2017;60:314-23. PMID: 27807598 DOI: $10.1007 / s 00125-016-4141-y$

Sankaranarayanan R, Ferlay J. Worldwide burden of gynaecological cancer: the size of the problem. Best Pract Res Clin Obstet Gynaecol. 2006;20:207-25. PMID: 16359925 DOI: $10.1016 / \mathrm{j}$. bpobgyn.2005.10.007

Sayer RA, Lancaster JM, Pittman J, Gray J, Whitaker R, Marks JR, Berchuck A. High insulin-like growth factor-2 (IGF-2) gene expression is an independent predictor of poor survival for patients with advanced stage serous epithelial ovarian cancer. Gynecol Oncol. 2005;96:355-61. PMID: 15661221 DOI: 10.1016/j.ygyno.2004.10.012

Schairer C, Fuhrman BJ, Boyd-Morin J, Genkinger JM, Gail MH, Hoover RN, Ziegler RG. Quantifying the Role of Circulating Unconjugated Estradiol in Mediating the Body Mass Index-Breast Cancer Association. Cancer Epidemiol Biomarkers Prev. 2016;25:105-13. PMID: 26637268 DOI: 10.1158/1055-9965.EPI-15-0687
Schmidt FM, Weschenfelder J, Sander C, Minkwitz J, Thormann J, Chittka T, Mergl R, Kirkby KC, Faßhauer M, Stumvoll M, Holdt LM, Teupser D, Hegerl U, Himmerich $\mathrm{H}$. Inflammatory cytokines in general and central obesity and modulating effects of physical activity. PLoS One. 2015;10:e0121971. PMID: 25781614 DOI: 10.1371/journal.pone.0121971

Schock H, Surcel HM, Zeleniuch-Jacquotte A, Grankvist K, Lakso $H \AA$, Fortner RT, Kaaks R, Pukkala E, Lehtinen M, Toniolo $P$, Lundin $E$. Early pregnancy sex steroids and maternal risk of epithelial ovarian cancer. Endocr Relat Cancer. 2014;21:831-44. PMID: 25270324 DOI: 10.1530/ERC-140282

Shah MM, Erickson BK, Matin T, McGwin G Jr, Martin JY, Daily LB, Pasko D, Haygood CW, Fauci JM, Leath CA 3rd. Diabetes mellitus and ovarian cancer: more complex than just increasing risk. Gynecol Oncol. 2014;135:273-7. PMID: 25220626 DOI: $10.1016 / \mathrm{j}$. ygyno.2014.09.004

Shen $Y$, Zhao Y, Yuan L, Yi W, Zhao R, Yi Q, Yong T. SPARC is over-expressed in adipose tissues of diet-induced obese rats and causes insulin resistance in 3T3-L1 adipocytes. Acta Histochem. 2014;116:158-66. PMID: 23910024 DOI: $10.1016 /$ j.acthis.2013.06.004

Siegel RL, Miller KD, Jemal A. Cancer statistics, 2018. CA Cancer J Clin. 2018;68:7-30. PMID: 29313949 DOI: 10.3322/caac. 21442

Smits A, Lopes A, Das N, Kumar A, Cliby W, Smits E, Bekkers R, Massuger L, Galaal K. Surgical morbidity and clinical outcomes in ovarian cancer - the role of obesity. BJOG. 2016;123:300-8. PMID: 26331299 DOI: 10.1111/14710528.13585

Spentzos D, Cannistra SA, Grall F, Levine DA, Pillay K, Libermann TA, Mantzoros CS. IGF axis gene expression patterns are prognostic of survival in epithelial ovarian cancer. Endocr Relat Cancer. 2007;14:781-90. PMID: 17914107 DOI: $10.1677 /$ ERC-06-0073

Torre LA, Bray F, Siegel RL, Ferlay J, Lortet-Tieulent J, Jemal A. Global cancer statistics, 2012. CA Cancer J Clin. 2015;65:87-108. PMID: 25651787 DOI: 10.3322/ caac. 21262

Teng Y, Zhang Y, Qu K, Yang X, Fu J, Chen W, Li X. MicroRNA-29B (mir-29b) regulates the Warburg effect in ovarian cancer by targeting AKT2 and AKT3. Oncotarget. 2015;6:40799-814. PMID: 26512921 DOI: 10.18632/oncotarget. 5695

Tyler CP, Whiteman MK, Zapata LB, Hillis SD, Curtis KM, McDonald J, Wingo PA, Kulkarni A, Marchbanks PA. The effect of body mass index and weight change on epithelial ovarian cancer survival in younger women: a long-term follow-up study. J Womens Health (Larchmt). 2012;21:865-71. PMID: 22663301 DOI: 10.1089/ jwh.2012.3487

Uddin S, Bu R, Ahmed M, Abubaker J, Al-Dayel F, Bavi $\mathrm{P}$, Al-Kuraya KS. Overexpression of leptin receptor predicts an unfavorable outcome in Middle Eastern ovarian cancer. Mol Cancer. 2009;8:74. PMID: 19765303 DOI: 10.1186/14764598-8-74 
Vigneri P, Frasca F, Sciacca L, Pandini G, Vigneri R. Diabetes and cancer. Endocr Relat Cancer. 2009;16:1103-23. PMID: 19620249 DOI: 10.1677/ERC-09-0087

Vrachnis N, Iavazzo C, Iliodromiti Z, Sifakis S, Alexandrou A, Siristatidis C, Grigoriadis C, Botsis D, Creatsas G. Diabetes mellitus and gynecologic cancer: molecular mechanisms, epidemiological, clinical and prognostic perspectives. Arch Gynecol Obstet. 2016;293:239-46. PMID: 26338721 DOI: $10.1007 / s 00404-015-3858-z$

Wallace IR, McKinley MC, Bell PM, Hunter SJ. Sex hormone binding globulin and insulin resistance. Clin Endocrinol (Oxf). 2013;78:321-9. PMID: 23121642 DOI: 10.1111/ cen. 12086

Wang B, Wood IS, Trayhurn P. Dysregulation of the expression and secretion of inflammation-related adipokines by hypoxia in human adipocytes. Pflugers Arch. 2007;455:479-92. PMID: 17609976 DOI: 10.1007/ s00424-007-0301-8

Weisberg SP, McCann D, Desai M, Rosenbaum M, Leibel RL, Ferrante AW Jr. Obesity is associated with macrophage accumulation in adipose tissue. J Clin Invest. 2003;112:1796808. PMID: 14679176 DOI: $10.1172 / J C I 200319246$

Wolk A, Gridley G, Svensson M, Nyrén O, McLaughlin JK, Fraumeni JF, Adam HO. A prospective study of obesity and cancer risk (Sweden). Cancer Causes Control. 2001;12:1321. PMID: 11227921 DOI: 10.1023/A: 1008995217664

Wuerkenbieke D, Wang J, Li Y, Ma C. miRNA-150 downregulation promotes pertuzumab resistance in ovarian cancer cells via AKT activation. Arch Gynecol Obstet. 2015;292:1109-16. PMID: 25986891 DOI: 10.1007/ s00404-015-3742-x

Wu X, Yan Q, Zhang Z, Du G, Wan X. Acrp30 inhibits leptin-induced metastasis by downregulating the JAK/ STAT3 pathway via AMPK activation in aggressive SPEC2 endometrial cancer cells. Oncol Rep. 2012;27:1488-96. PMID: 22327423

Yang HS, Yoon C, Myung SK, Park SM. Effect of obesity on survival of women with epithelial ovarian cancer: a systematic review and meta-analysis of observational studies. Int J Gynecol Cancer. 2011;21:1525-32. PMID: 22080892 DOI: $10.1097 /$ IGC.0b013e31822eb5f8
Ye J, Yao Z, Tan A, Gao Y, Chen Y, Lin X, He R, Tang R, Hu $Y$, Zhang $H$, Yang $X$, Wang $Q$, Jiang $Y$, Mo Z. Low Serum Sex Hormone-Binding Globulin Associated with Insulin Resistance in Men with Nonalcoholic Fatty Liver Disease. Horm Metab Res. 2017;49:359-64. PMID: 28282659 DOI: $10.1055 / \mathrm{s}-0043-102690$

Ying W, Tseng A, Chang RC, Wang $H$, Lin $Y L$, Kanameni $S$, Brehm T, Morin A, Jones B, Splawn T, Criscitiello M, Golding MC, Bazer FW, Safe S, Zhou B. miR-150 regulates obesity-associated insulin resistance by controlling $B$ cell functions. Sci Rep. 2016;6:20176. PMID: 26833392 DOI: 10.1038/srep20176

Yu H, Rohan T. Role of the insulin-like growth factor family in cancer development and progression. J Natl Cancer Inst. 2000;92:1472-89. PMID: 10995803 DOI: 10.1093/ jnci/92.18.1472

Yu $H$, Pardoll D, Jove R. STATs in cancer inflammation and immunity: a leading role for STAT3. Nat Rev Cancer. 2009;9:798-809. PMID: 19851315 DOI: $10.1038 / \mathrm{nrc2734}$

Yu T, Wang Y, Fan Y, Fang N, Wang T, Xu T, Shu Y. CircRNAs in cancer metabolism: a review. J Hematol Oncol. 2019;12:90. PMID: 31484561 DOI: 10.1186/s13045-019-0776-8

Zamorano AS, Hagemann AR, Morrison L, Lee JA, Liao LM, Brinton LA, Park Y, Toriola AT. Pre-diagnosis body mass index, physical activity and ovarian cancer mortality. Gynecol Oncol. 2019;155:105-11. PMID: 31383570 DOI: 10.1016/j.ygyno.2019.07.025

Zeleznik OA, Eliassen AH, Kraft P, Poole EM, Rosner BA, Jeanfavre S, Deik AA, Bullock K, Hitchcock DS, Avila-Pacheco J, Clish CB, Tworoger SS. A Prospective Analysis of Circulating Plasma Metabolites Associated with Ovarian Cancer Risk. Cancer Res. 2020;80:1357-67. PMID: 31969373 DOI: 10.1158/0008-5472.CAN-19-2567

Zhang M, Xie X, Lee AH, Binns CW, Holman CD. Body mass index in relation to ovarian cancer survival. Cancer Epidemiol Biomarkers Prev. 2005;14:1307-10. PMID: 15894691 DOI: $10.1158 / 1055-9965 . E P I-04-0519$

Zhu J, Wu G, Song L, Cao L, Tan Z, Tang M, Li Z, Shi D, Zhang $S$, Li J. NKX2-8 deletion-induced reprogramming of fatty acid metabolism confers chemoresistance in epithelial ovarian cancer. EBioMedicine. 2019;43:238-52. PMID: 31047858 DOI: $10.1016 /$ j.ebiom.2019.04.041 